\title{
ЮРИДИЧНИЙ АНАЛІЗ СКЛАДУ ПЕРЕВИЩЕННЯ ВІЙСЬКОВОЮ СЛУЖБОВОЮ ОСОБОЮ ВЛАДИ ЧИ СЛУЖБОВИХ ПОВНОВАЖЕНЬ
}

Кізюн О. П.

Стаття присвячена юридичному аналізу елементів складу злочину, передбаченого статтею 426-1 Кримінального кодексу України «Перевищення військовою службовою особою влади чи службових повноважень». У cmammi детально розглянуті й охарактеризовані елементи складу злочину: об'єкт складу злочину, об'єктивна сторона складу злочину, суб'єкт складу злочину та суб'єктивна сторона складу злочину. Проаналізовано види об'єктів злочину перевищення військовою службовою особою влади чи службових повноважень. Встановлено, що для розглядуваного злочину велике значення має обов'язкова наявність додаткового факультативного безпосереднього об'єкта злочину. Також детально розглянуто об'єктивну сторону перевищення військовою службовою особою влади чи службових повноважень. Встановлено, що перевищення військовою службовою особою влади чи службових повноважень належить до матеріальних складів злочинів.

Зазначено, що видами перевищення влади чи службових повноважень називають дії, які: 1) входять до компетенції іншої службової особи або органу (вища службова особа, службова особа іншого відомства та інші); 2) можуть бути здійснені тільки колегіально, або, відповідно до порядку, встановленого законом, погоджені з іншими службовими особами чи органом; 3) могли бути вчинені самою службовою особою тільки в разі наявності особливих обставин, зазначених у законі; 4) ніхто, за жодних обставин не має права їх учиняти (тобто вчинені винним дії не входять до компетенції жодної службової особи).

Суб'єктом розглядуваного складу злочину $є$ особа, яка наділена ознаками, що передбачені у примітці до статті 425 Кримінального кодексу України.

Отримані результати дослідження можна використовувати як обгрунтовані пропозиції щодо вдосконалення законодавства, яке регулює порядок кримінальної відповідальності військової службової особи під час несення або проходження військової служби.

Ключові слова: військові службові особи, військовослужбовці, військова служба, перевищення влади, службові повноваження, об'єкт злочину, об'єктивна сторона, суб'єктивна сторона, суб'єкт злочину.

๑ Кізюн О. П., 2020
Kiziun O. P. Legal analysis of the structure of excess by a military officer of power or office

The article is devoted to the legal analysis of the elements of the crime under Article 426-1 of the Criminal Code of Ukraine "Excess of power or official authority by a military official". The article considers and characterizes in detail the elements of the crime: the object of the crime, the objective side of the crime, the subject of the crime and the subjective side of the crime. The types of objects of crime of excess of power or official authority by a military official are analyzed. It is established that for the crime in question it is important to have an additional optional direct object of the crime. The objective aspect of the military official's excess of power or official authority is also considered in detail. It is established that the excess of power or official authority by a military official refers to the material components of crimes.

It is noted that the types of excess of power or official authority are actions that: 1) are within the competence of another official or body (superior official, official of another department, etc.); 2) may be carried out only collegially, or, in accordance with the procedure established by law, agreed with other officials or body; 3) could be committed by the official himself only in the presence of special circumstances specified in the law; 4) no one, under any circumstances, has the right to commit them (i. e. the actions committed by the perpetrator are not within the competence of any official).

The subject of the crime in question is a person who is endowed with the features provided for in the note to Article 425 of the Criminal Code of Ukraine.

The obtained results of the research can be used as substantiated proposals for improving the legislation governing the criminal liability of a military officer during military service.

Key words: military officials, servicemen, military service, excess of power, official authority, object of crime, objective side, subjective side, subject of crime.

Постановка проблеми та іï актуальність. Посилення законності і правопорядку української армії - це найважливіше завдання держави в умовах військово-збройної агресії. У таких умовах важливо забезпечити дотримання військової дис- 
ципліни, отже, боєготовності й обороноздатності країни. Водночас вирішення вказаних завдань держави повинно здійснюватися в кількох напрямах, серед яких велике значення має вдосконалення чинного законодавства про військовий обов'язок і військову службу.

Одне із центральних місць у системі заходів забезпечення військової дисципліни належить нормам кримінального права, особливо розд. XIX Кримінального кодексу України (далі КК України).

Кримінальна відповідальність військовослужбовців, військовозобов'язаних та резервістів під час проходження ними зборів передбачена розд. XIX «Злочини проти встановленого порядку несення військової служби (військові злочини)». Розд. XIX містить 34 статті КК України, суб'єкт яких тільки спеціальний, це - військовослужбовці, військовозобов'язані та резервісти під час проходження ними зборів. Для зміцнення правопорядку у Збройних силах України та з метою дотримання принципу невідворотності покарання Законом України № 290-VIII від 7 квітня 2015 р. «Про внесення зміни до Кримінального кодексу України щодо перевищення військовою службовою особою влади чи службових повноважень» Кодекс було доповнено ст. 426-1 «Перевищення військовою службовою особою влади чи службових повноважень» [1].

Аналіз останніх досліджень і публікацій. Питання кримінально-правової характеристики злочинів у сфері службової діяльності частково розглядали В. Клименко, М. Мельник, М. Хавронюк [2, с. 10], П. Андрушко, В. Навроцький, М. Панов, С. Харитонов, М. Карпенко [3, с. 161] та інші. Питання військових службових злочинів вивчалися на рівні дисертаційних досліджень М. Хавронюком («Кримінальна відповідальність за перевищення військовою посадовою особою влади чи посадових повноважень», 1998 р.), Б. Леоновим («Кримінальна відповідальність за бездіяльність військової влади (ст. 426 КК України)», 2004 р.), М. Туркотом («Кримінальна відповідальність за зловживання військовою службовою особою владою або службовим становищем», 2007 р.) [3, c. 161].

Метою статті $\epsilon$ характеристика елементів складу злочину, передбаченого ст. 426-1 КК України «Перевищення військовою службовою особою влади чи службових повноважень».

Виклад основного матеріалу. Традиційно юридичний аналіз складу злочину необхідно починати із визначення об'єкта злочину. Об'єкт злочину - це те, що охороняється законом, чому саме в результаті вчинення злочину завдається шкода. Об'єкт злочину - це обов'язковий елемент складу будь-якого злочину.

У сучасній теорії кримінального права немає єдиної думки щодо класифікації об'єкта злочинного посягання. Одні автори пропонують розділити об'єкти злочину на загальний, родовий і безпосередній, інші виділяють загальний, типовий, родовий і безпосередній. Але, оскільки в науці кримінального права існує стала класифікація поділу об'єктів злочину за ступенем спільності охоронюваних кримінальним законом суспільних відносин на загальний, родовий і безпосередній, а за основним спрямуванням злочинного посягання - на основний (головний) безпосередній об'єкт злочину, додатковий необхідний (обов'язковий) безпосередній об'єкт злочину та додатковий факультативний (необов'язковий) безпосередній об'єкт злочину [4, с. 15]. Вказана класифікація об'єктів злочину натепер домінує, тому під час проведення аналізу діяння, передбаченого ст. 426-1 КК України, ми будемо використовувати саме іï.

Родовим об'єктом перевищення військовою службовою особою влади чи службових повноважень виступають суспільні відносини, що регулюють встановлений законом порядок несення або проходження військової служби.

Військова служба - це державна служба особливого характеру, яка полягає у професійній діяльності придатних до неї за станом здоров'я і віком громадян України (за винятком випадків, визначених законом), іноземців та осіб без громадянства, пов'язаній з обороною України, її незалежності та територіальної цілісності [5].

Крім того, на нашу думку, до родового об'єкта злочину, що розглядається, можна також віднести і конституційний устрій та безпеку держави загалом, з огляду на законодавче визначення військової служби.

Основним безпосереднім об'єктом перевищення військовою службовою особою влади чи службових повноважень виступають суспільні відносини, які виникають у зв'язку з виконанням військовою службовою особою владних, організаційно-розпорядчих чи адміністративно-господарських функцій, покладених на неї відповідним апаратом управління (командування, начальник, органи державної влади тощо) [4, с. 1036].

Оскільки перевищення військовою службовою особою влади чи службових повноважень призводить до порушення прав і законних інтересів 
громадян, то поряд з основним об'єктом існують і додаткові безпосередні об'єкти злочину. Додатковим факультативним безпосереднім об'єктом можуть виступати здоров'я, честь і гідність особи, суспільні відносини власності, безпека довкілля тощо [4, с. 1036]. Завдання шкоди такому додатковому безпосередньому об'єкту $є$ обов'язковою умовою кримінальної відповідальності і водночас критерієм розмежування службового злочину від дисциплінарного проступку. Тобто незавдання шкоди такому об'єкту означає відсутність конструктивної ознаки складу злочину - наслідків злочину.

Наступну групу ознак, що характеризують перевищення військовою службовою особою влади чи службових повноважень, утворює об'єктивна сторона злочину - зовнішній прояв поведінки злочинця, ознаки якої вказані в законі повніше за інші елементи складу злочину.

Закон характеризує об'єктивну сторону перевищення військовою службовою особою влади чи службових повноважень як умисне вчинення дій, які явно виходять за межі наданих цій особі прав чи повноважень; застосування нестатутних заходів впливу щодо підлеглого або перевищення дисциплінарної влади; застосування насильства щодо підлеглого; учинення зазначених діянь із застосуванням зброї. Об'єктивна сторона перевищення військовою службовою особою влади чи службових повноважень складається із трьох обов'язкових ознак: 1) злочинних дій; 2) суспільно небезпечних наслідків; 3) причинного зв'язку між діями і суспільно небезпечними наслідками. Зрозуміло, що перевищення військовою службовою особою влади чи службових повноважень належить до матеріальних складів злочинів. Крім того, наслідки у вигляді істотної шкоди обов'язкові для всіх перелічених суспільно небезпечних дій, крім застосування насильства щодо потерпілого.

Диспозиція ч. 1 ст. 426-1 КК України вказує: «Перевищення військовою службовою особою влади чи службових повноважень, тобто умисне вчинення дій, які явно виходять за межі наданих цій особі прав чи повноважень <...>». Отже, необхідно уточнити поняття «повноваження», чіткого визначення якого законодавство не дає. Існує кілька думок щодо визначення цього терміна. Деякі вчені вважають, що повноваження це сукупність прав і обов'язків державних органів і громадських організацій, а також посадових та інших осіб, закріплених за ними у встановленому законодавством порядку для здійснення покладених на них функцій [6, с. 639]. Інші - що повноваження варто розглядати як право, надане кому-небудь для здійснення чогось, компетенцію, доручення [7, с. 469]. На нашу думку, перше визначення $є$ більш широким, оскільки включає всі елементи повноважень. Тому під час встановлення вини обвинуваченої військової службової особи у вчиненні злочину, передбаченого ст. 426-1 КК України, необхідно 3'ясувати, якими конкретно нормативно-правовими актами, а також іншими документами встановлені права й обов'язки обвинуваченої військової службової особи, які саме норми (стаття, частина, пункт) порушені.

Перевищення військовою службовою особою влади означає, що вказана особа вчиняє умисні дії, які явно виходять за межі наданих їй прав, пов'язаних із відданням наказів, вказівок, розпоряджень, обов'язкових для виконання іншими особами [4, с. 1036]. У кримінально-правовій літературі видами перевищення влади чи службових повноважень називають дії, які: 1) входять до компетенції іншої службової особи або органу (вища службова особа, службова особа іншого відомства й інші); 2) можуть бути здійснені тільки колегіально, або, відповідно до порядку, установленого законом, погоджені з іншими службовими особами чи органом; 3) могли бути вчинені самою службовою особою тільки в разі наявності особливих обставин, зазначених у законі; 4) ніхто за жодних обставин не має права їх учиняти (тобто вчинені винним дії не входять до компетенції жодної службової особи).

Застосування нестатутних заходів впливу щодо підлеглого полягає у вчиненні умисних дій, які виходять за межі компетенції військової службової особи і полягають у здійсненні впливу на підлеглого всупереч вимогам, установленим у статутах Збройних сил України [4, с. 1037].

Перевищення дисциплінарної влади - це ухвалення військовою службовою особою рішення про застосування до підлеглого заходів дисциплінарного впливу, що виходять за межі їі компетентності [4, с. 1037]. Зокрема, це може бути накладенням заходів дисциплінарного впливу, які належать до компетенції вищого командира, або притягнення до дисциплінарної відповідальності за дії, які не $є$ дисциплінарним проступком.

Під застосуванням насильства щодо підлеглого варто розуміти застосування як фізичного, так і психічного впливу військовою службовою особою щодо особи, яка перебуває в їі підпорядкуванні.

Одним зі складних питань кваліфікації перевищення військовою службовою особою влади чи службових повноважень $€$ встановлення й оцінка наслідків, що спричинені досліджува- 
ним злочином. Злочинні наслідки діляться на матеріальні і нематеріальні. У складі матеріальних злочинів наслідки чітко визначені у змісті статті. У ч. 1 ст. 426-1 КК України вони визначені так: «<...> якщо ці дії заподіяли істотну шкоду». У ч. 3 ст. 426-1 КК України визначені так: «<...> якщо вони спричинили тяжкі наслідки».

Третьою ознакою об'єктивної сторони є причинний зв'язок між діями і наслідками, що спричинені цими злочинними діями. Про наявність причинного зв'язку у складі перевищення військовою службовою особою влади чи службових повноважень можна говорити лише тоді, коли настання суспільно небезпечних наслідків стало можливим лише через учинення військовою службовою особою протиправної дії. Для причинного зв'язку в разі перевищення військовою службовою особою влади чи службових повноважень характерна відсутність тривалості в часі, тобто проміжок часу між учиненими діями і злочинними наслідками відсутній.

Отже, причинний зв'язок повинен відповідати таким критеріям: 1) часовому критерію; 2) діяння повинно бути необхідною умовою настання наслідків; 3) між діянням і наслідками повинний бути закономірний, а не випадковий зв'язок.

Наступну групу ознак, що характеризують перевищення військовою службовою особою влади чи службових повноважень, утворюють особливості суб'єкта злочину. Під суб'єктом злочину у кримінальному праві розуміють «фізичну осудну особу, яка на момент учинення злочину досягла віку кримінальної відповідальності» [9, с. 34]. Вказане визначення відображає лише загальні ознаки суб'єкта. Суб'єкт же будь-якого службового злочину - спеціальний.

Суб'єктом розглядуваного складу злочину $\epsilon$ особа, яка наділена ознаками, що передбачені у примітці до ст. 425 КК України: «Під військовими службовими особами розуміються військові начальники, а також інші військовослужбовці, які обіймають постійно чи тимчасово посади, пов'язані з виконанням організаційно-розпорядчих або адміністративно-господарських обов'язків, або виконують такі обов'язки за спеціальним дорученням повноважного командування» [1].

Військовим начальником є особа, яка за характером своєї служби має підлеглих і наділена правом віддавати їм накази, обов'язкові до виконання [4, с. 1034].

Начальниками за службовим становищем і званням, яких можна віднести до службових осіб, $є$ : 1) особи, які обіймають відповідні військові посади згідно зі штатом (наприклад, командир відділення, роти, начальник речової служби); 2) особи, що тимчасово виконують обов'язки відповідної військової посади, а також тимчасово виконують функції посадової особи за спеціальним повноваженням; 3) особи цивільного персоналу $є$ начальниками для підлеглих військовослужбовців відповідно до займаної штатної посади; 4) начальники за військовим званням, визначені в Дисциплінарному статуті Збройних сил України [8].

Вказаний в Законі характер виконуваних функцій дозволяє чітко виокремити коло осіб, що підпадають під поняття «військова службова особа», унеможливлює розширення кола таких осіб.

Виконання військовими службовими особами організаційно-розпорядчих або адміністративно-господарських обов'язків означає, що вказані особи виконують управлінські функції не ззовні, а зсередини організації (Збройні сили України), де самі проходять військову службу. Інакше кажучи, вони не можуть ухвалювати рішення, обов'язкові для виконання будь-ким, крім персоналу даної організації, однак усередині організації вони наділені управлінськими повноваженнями.

Для кращого з'ясування характеристики військових службових осіб із погляду їхнього структурного положення визначені місця проходження ними служби в ч. 2 ст. 401 КК України: «<...> військовослужбовці Збройних Сил України, Служби безпеки України, Державної прикордонної служби України, Національної гвардії України та інших військових формувань, утворених відповідно до законів України, Державної спеціальної служби транспорту, Державної служби спеціального зв'язку та захисту інформації України, а також інші особи, визначені законом» [1].

Наступну групу ознак, що характеризують досліджуваний злочин, утворює суб'єктивна сторона, що охоплює внутрішні процеси, пов'язані із психікою суб'єкта. Їх установлення надзвичайно важливе, оскільки відповідальність особи за вчинене можлива лише в межах, які охоплюються суб'єктивною стороною. Суб'єктивна сторона злочину визначається як психічне ставлення особи до вчинюваного нею суспільно небезпечного діяння і його наслідків. До ознак, які утворюють суб'єктивну сторону злочину, віднесені вина, мотив і мета вчинення злочину. Вина $\epsilon$ обов'язковою ознакою будь-якого складу злочину. Мотив і мета $€$ факультативними ознаками суб'єктивної сторони, однак якщо вони прямо описані в нормі Особливої частини КК України, то вони стають для цих складів злочинів обов' язковими [9, с. 41]. 
У характеристиці вказаного елемента складу перевищення військовою службовою особою влади чи службових повноважень будемо дотримуватися позиції, що у структуру суб'єктивної сторони входять вина, мотив і мета.

У науці кримінального права існує думка про те, що в основному вина у складі перевищення військовою службовою особою влади чи службових повноважень може бути лише у формі прямого або непрямого умислу. На наш погляд, така думка $\epsilon$ правильною. Так, інтелектуальний елемент умислу в даному разі складається з усвідомлення особою суспільно небезпечного характеру своїх дій і передбачення можливості або неминучості настання суспільно небезпечних наслідків. По-перше, це означає, що особа, коли вчиняє вказаний злочин, усвідомлює вихід за межі наданих їй повноважень, тобто розуміє, що вчиняє дії, які не входять в ії компетенцію. По-друге, у разі перевищення влади чи службових повноважень особа завжди усвідомлює протиправність учинюваних дій.

Другою ознакою інтелектуального елемента умислу $\epsilon$ передбачення можливості або невідворотності (прямий умисел), або лише тільки можливості (непрямий умисел) настання суспільно небезпечних наслідків, які випливають з усвідомлення суспільної небезпеки вчинюваний дій.

Наступною ознакою суб'єктивної сторони перевищення військовою службовою особою влади чи службових повноважень $\epsilon$ мотив як усвідомлене спонукання особи до вчинення злочину. Відповідно до ст. 91 Кримінального процесуального кодексу України, мотиви вчинення злочинів підлягають доказуванню в будь-якому кримінальному провадженні.

Ще однією ознакою суб'єктивної сторони складу злочину $\epsilon$ мета - уявлення про бажаний результат, якого особа бажає досягти, коли вчиняє злочин. Оскільки мета свідчить про бажання особи досягти певного наслідку, то вона наявна тільки в разі вчинення злочинів із прямим умислом [9, с. 47].

Отже, перевищення військовою службовою особою влади чи службових повноважень може вчиняться як із прямим, так і з непрямим умислом. 3'ясування мотивів i мети перевищення влади чи службових повноважень необхідне для правильного призначення покарання, дотримання принципу індивідуалізації кримінальної відповідальності та покарання.

Висновки. У підсумку варто зазначити, що перевищення військовою службовою особою влади чи службових повноважень у будь-якій із розглянутих форм повинно бути здійснене безпосередньо під час виконання таких службових повноважень. Учинення дій, пов'язаних із використанням влади чи службових повноважень, не може бути кваліфікованим за ст. 426-1 КК України, якщо військова службова особа не перебувала при виконанні влади чи службових повноважень. Відповідальність за перевищення військовою службовою особою влади чи службових повноважень настає в разі порушення прав чи законних інтересів громадян або охоронюваних інтересів суспільства і держави, якщо особа усвідомлювала, що діє поза межами покладених на неї службових повноважень.

\section{Література}

1. Кримінальний кодекс України : Закон України від 5 квітня 2001 р. № 2341-ІІІ. Верховна Рада України. URL: https://zakon.rada.gov.ua/laws/show/ 2341-14\#Text.

2. Клименко В., Мельник Н., Хавронюк Н. Уголовная ответственность за должностные преступления. Киев, 1996. 160 с.

3. Карпенко М. До питання окремих ознак об'єктивної сторони військових службових злочинів у сфері управлінської діяльності. Актуальні проблеми вітчизняної юриспруденції. 2018. № 4. С. 161-164.

4. Науково-практичний коментар Кримінального кодексу України / Д. Азаров та ін. ; за заг. ред. О. Джужі, А. Савченка, В. Чернея. 2-ге вид., переробл. і доповн. Київ : Юрінком-Інтер, 2018. 1104 с.

5. Про військовий обов'язок і військову службу : Закон України від 25 березня 1992 р. № 2232-XII. Bepховна Рада України. URL: https://zakon.rada.gov.ua/ laws/show/2232-12\#Text.

6. Великий енциклопедичний юридичний словник / за ред. Ю. Шемшученка. Київ : Юрид. думка, 2007. 992 c.

7. Новий тлумачний словник української мови : у 4-х т. / уклад. В. Яременко, О. Сліпушко. Київ : Аконіт. 1998. Т. 3.928 с.

8. Про Дисциплінарний статут Збройних Сил України : Закон України від 24 березня 1999 р. № 551-XIV. Верховна Рада України. URL: https: / /zakon.rada.gov. ua $/$ cgi-bin/laws $/$ main.cgi?nreg=551\%2D14\&p=1143970 339900570\#Text.

9. Кримінальне право України. Загальна частина : навчальний посібник / за ред. О. Омельчука. Київ : Правова єдність, 2010. 208 с.

Кізюн О. П., аспірант кафедри кримінального, кримінально-виконавчого права та кримінології Академії державної пенітенціарної служби 